\title{
Business ethics: A connection to good corporate governance implementation
}

\author{
Sambas Ade Kesuma1; Risanty²; Muhammad Husni Mubarok ${ }^{3}$; \\ Citra Marisa ${ }^{4}$ \\ 1), 2), 4) Accounting Departement, Universitas Sumatera Utara, Indonesia \\ 3) Accounting Departement, Politeknik Negeri Sriwijaya, Indonesia \\ *To whom correspondence should be addressed.Email: sambas.usu@gmail.com
}

\begin{tabular}{|l|l|l|l|l|}
\hline DOI: & Received: & Revised: & Accepted: & Published: \\
10.22437/ppd.v8i1.7877 & 22.10 .2019 & 25.05 .2020 & 07.06 .2020 & 12.06 .2020 \\
\hline
\end{tabular}

\begin{abstract}
The main purpose of this study is to discuss business ethics and good corporate governance implementation. Business ethics is the foundation of good corporate governance implementation in a company. The existence of ethics in the company is expected to be a benchmark for measuring moral values, especially policies. It is also expected that the application of good business ethics elevates the implementation of good corporate governance. The establishment of supervisory institutions in public sector organizations is also expected to be the best way to eliminate the ethical violation. Thus, good business practices and the environment in Indonesia can be achieved.
\end{abstract}

Keywords: Business ethic, Good corporate governance, Public sector

JEL Classification: M1, M2

\section{INTRODUCTION}

In the business world, companies that are engaged in services, trade, and manufacturing that have developed rapidly will always be faced with the problem of management and control of the company. So that companies can survive and thrive in the competitive business environment, then the company needs to make efforts to secure and manage the company. One of the efforts is to implement good corporate governance in the company.

In the implementation of good corporate governance in a company, it is inseparable from the rules that must be accepted and obeyed by the company, both legal rules and moral or ethical rules (Risanty \& Kesuma, 2019; Oluwafisoye, \& Akande, 2013). The Indonesian Institute for Corporate Governance (IICG) noted that one of the main reasons for a company implementing good corporate governance in compliance with regulations and ethics.

The business ethics practices require employees and company leaders to do everything on behalf of the company and it can be a standard as well as guidance for all employees including management (Arjoon, 2005; Brooks \& Dunn, 2012; Ernawan, 2016). Business ethics in a company is a form of the implementation of good corporate governance principles (Zabihollah, 2009).

Corporate governance emerged in the 1990s when deregulation and internationalization of the capital market began. Then followed by institutional 
investment through pension funds start to grow in the United States and the United Kingdom (Kamal, 2010). Corporate governance is more related to the essential factor in the company such as ownership, control, and corporate accountability. And also how a company encourages economic objectives associated with a number of ethical values and broader social considerations (Ramakrishnan, 2007).

Effective corporate governance is very important especially for companies in developing countries because it can generate clarity, managerial excellence, and help increase capital (Doidge, Karolyi, \& Stulz, 2007; Silanont, 2012).

Companies in developing countries tend to prefer to spend a minimum on governance, and determination of the minority stakeholder's rights usually resolved at the state level, not at the enterprise level (Doidge, Karolyi \& Stulz, 2007). Evidence from developing countries such as Lebanon shows that governance practices are relatively late to develop and there is limited study on governance practices in particular state-owned enterprises environment (El-Kassar, Messarra \& Elgammal, 2015). Meanwhile, in Egypt through the Egyptian Institute of Directors become initiators in introducing a system of corporate governance in the Middle East and North Africa (MENA) region. This introduces a corporate governance code for state-owned enterprises and small and medium-sized enterprises (Gamal, 2009).

In Indonesia, since the economic crisis at the end of 1997, problems regarding good governance began to emerge. This has caused many companies to reform and change governance in the management of companies, including Indonesian state-owned enterprises. The reformation of a state-owned enterprise in Indonesia was marked by the release of State-Owned Enterprises Ministerial Decree No. KEP-117/M-MBU/2002 dated July 31, 2002, regarding the application of good corporate governance principles in Indonesia. This is one of the efforts of the Indonesia Ministry of State-Owned Enterprises to strengthen the implementation of good corporate governance in every state enterprise to compete in the evolving business world.

Nevertheless, Indonesian state-owned enterprises have a strong determination to implement good corporate governance principles. Indonesian state-owned enterprises in implementing good corporate governance practices should focus on the encouragement of the application of good corporate governance principles. One effort that can be done is by improving compliance with ethics (Zabihollah, 2009).

Several previous studies have emphasized the important role of ethics in corporate governance (El-Kassar, Messarra \& Elgammal, 2015; Othman \& Rahman, 2011; Othman, Rahman \& Shamsudin, 2012). In Malaysia, Othman \& Rahman (2011) examined the role of ethics in corporate governance. The results show that ethical positions, ethical principles, as well as the ethical structure are important requirements for promoting governance practices. Meanwhile, Othman, Rahman \& Shamsudin (2012) find that ethics plays an essential role in corporate governance practices. In the context of Lebanon and Egypt, El-Kassar, Messarra \& Elgammal (2015) point out that a higher level of ethics and practices lead to a greater level of corporate governance practices.

The findings of previous studies show a significant influence on business ethics on the implementation of good corporate governance in Indonesia. A study on the effect of business ethics and corporate culture on the implementation of good corporate governance principles conducted by Ariesti, Yolanda \& Hia (2014) found a positive and significant effect between business ethics on the implementation of the principles of good corporate governance. Meanwhile, Sari (2011) also conducted a study on the effect of business ethics, code of conduct, shareholders and dividend policy on good corporate governance implementation. The result of this study finds a significant effect of business ethics, code of conduct and policies on the implementation of good corporate governance. 
From the results of these studies, it appears that business ethics is an important factor in promoting good corporate governance implementation.

The objective of this paper is to discuss the concept of business ethics and the relationship to good corporate governance implementation. Further, this paper consists of several sections as follows. Section one presents the background and the concept of the business ethic. Section two provides a brief discussion related to the principles of business ethics. Section three discusses the problems in business ethics. Section four provides discussion related to the function of business ethics and its relation to good corporate governance. Finally, section five presents conclusions and recommendations.

\section{BUSINESS ETHICS: A BACKGROUND AND CONCEPT}

Business ethics and values are essential elements in a competitive business environment. Through applying the proper business ethics, all business activities will be able to generate various benefits, both material and non-material benefits such as good image, trust, and sustainability of the company (Ariesti, Yolanda \& Hia, 2014).

Johnson \& Scholes (1998) state that ethics is a branch of philosophy, the main objective is to study behavior, both moral and immoral. To providing reasonable considerations and finally reaching an adequate recommendation which is certainly acceptable to a particular group or individual. Also, Petersen (2013) postulates that ethics is a set of principles of right conduct or a system of moral principles.

Moreover, the Encyclopedia of Economics, Business and Management states that business ethics are the norms or values that guide the behavior and actions of the entrepreneur and the managers of these organizations (Magdalena, 1992). Meanwhile, Bertens (2000) define business ethics as a science of what is good and what is bad, about what people should do and what they should not do that applies in business practices

From the above definition, it can be concluded that business ethics concentrates on moral norms and values held by individuals, groups, and companies. Moreover, business ethics is a study of good and bad aspects of business interactions with stakeholders by using management and legal knowledge to achieve the goals of the company.

The background to the formulation of a business ethic is a powerful way to institutionalize ethics in the structure and activities of a company. Business ethics is a form of application of the principles in the company (Yosephus, 2010). Business ethics has a very essential role, which if it can be applied consistently, then it can form a solid company and has high competitiveness (Oluwafisoye, \& Akande, 2013). Because the core of the business is mutual trust then honesty is the main factor. Honesty is one of the principles of business ethics. Thus, business ethics becomes a decisive factor in business success and is a form of translation of the practice of good corporate governance principles in the company (Effendi, 2005). If the company has its ethics, it means that the company has several advantages compared to companies that do not have it.

In general, the purpose of business activities is not merely to gain the maximum profit by justifying any means. Companies that run their business activities with the appropriate ethics does not mean not being able to compete with competitors, it may be considered by their consumers as a committed to good ethics (Sabirin, 2016).

Gaining profits by not implementing business ethics in a company and dishonesty of employees can lead to a deterioration of business (Ernawan, 2016; Preble \& Reichel, 1998; Sabirin, 2016). Meanwhile, the company that cares about the interests of all individuals involved in business activities will be able to maintain the continuity of its business (Ernawan, 2016). In addition, running company operations with good ethics and trust will be able to make overall business activities better, both for consumers or users and also for all stakeholders who are interested in it (Akman, 2011). 
There are seven important points obtained by a company through the implementation of business ethics (Sukrisno, 2012), among others: 1) Increased company credibility. Applying appropriate business ethics internally, each employee will follow the same ethical standards. They will also take similar policies, decisions and procedures in every activity and cases that may encounter; 2) Remove the gray area in ethics. For instance, the bribery, the use of child labor and company obligations to protect the environment and surrounding communities; 3) Explains how a company is capable to assess its social responsibility; 4) Establish a mechanism that allows for self-regulation, both for internal companies and their business environments; 5) For listed companies, the application of good ethics is capable of improved investor confidence and at the same time attracts the interest of potential investors; 6) Enhances competitive advantage in a company; 7) Establish a corporate image (positive image) and for long-term goals, able to maintain the company's sustainability.

\section{WHY DOES A BUSINESS MUST BE ETHICAL?}

Why does a business need ethics? Isn't the activity of business only aimed to gain profit as much as possible? Will the ethical behavior adopted by the company prevent them from competing with their competitors?

To answer these questions, Post, Preston, \& Sachs (2002) explains seven reasons that encourage a company to conduct its business ethically, among others: 1) Realizing public expectations that the company operates ethically. A company that ignores ethical issues will be subject to criticism and even punishment. For example, a company related to a case of gratuity in connection with a program or project. This bribe will benefit certain individuals or groups. Obviously, the bribery act is unethical. This makes the company's stakeholders will be disappointed. And for companies that run unethical and immoral businesses, they will be criticized and even deal with penalties; 2) Prevent a company from taking actions that are detrimental to other stakeholders. For example, the unprofessional management of a landfill conducted by a company. This will result in a landslide disaster that has befallen the population of the surrounding population and cause losses to the community around the landfill. Another example is the Lapindo Mudflow problem. As a result, the negative effects are truly extraordinary. The damage resulted in economic disruption, especially East Java. The loss caused by the mudflow has hampered eroded economic potential due to loss of economic activity. Not to mention the immaterial losses suffered by the surrounding community, which cannot be paid no matter how much its value; 3) Improve the performance of the company. There have been many studies that show a significant relationship between corporate control that emphasizes the implementation of ethics and responsible behavior on the one hand with better organizational performance on the other hand. The results of these studies are believed that when applied in the context of Indonesian companies, then it is likely to have a positive impact on the performance of companies in Indonesia which will ultimately impact the progress of the country's economy; 4) Improve the quality of business relationships by implementing business ethics such as commitment, honesty, and antibribery. The application of business ethics such as honesty, commitment and anti-bribery will elevate trust between the parties involved in business relations with other parties. If the application of this ethic is carried out properly, then it will be able to minimize various cases of corruption, collusion, and other abuses in Indonesia in general. And also capable to educate and increase the morale of the nation in particular; 5) Prevent a company from avoiding abuse by employees or competitors. For example, a fraud act such as collusion and the misuse of company assets committed by the owner or leaders and other employees of the company. This is one of the critical factors causing company disaster and bankruptcy compared to other factors. Therefore, as mentioned above that the application 
of ethics such as honesty, commitment, and dedication is the essential factor in elevating a company; 6) Avoiding violations of workers' rights. A company is considered ethically if the company fulfills workers' normative rights. Workers' normative rights such as adequate salary and working conditions, implementation of a fair work assessment, a clear reward, and punishment policy. At the time of making a decision that could have an impact on workers, a company must pay attention to the expected reaction by the labor union. As representatives of workers, labor unions can accommodate the acquisition of normative rights that must be obtained by workers, in accordance with labor laws and applicable government regulations. The imposition of the will or unethical act unilaterally by the employer could result in strikes and mass demonstrations that could harm the company; 7) Prevent a company from a legal issue as a result of not applying business ethics. A company is required to implement business ethics in conducting its business. In order to prevent (represented by the leaders of the company) from getting legal sanctions because they have conducted their business unethically.

Ip (2003) suggests several key features of business ethics in the context of a stateowned enterprise environment: 1) A high level of convergence of values and shared vision. The majority of employees must be able to accept the mission, vision, principles and the company's core values. The company must guarantee that the business must be ethical, and the company takes ethics seriously. Employees must be proud to be members of the company so this shows that the company is very ethical regarding relationships with its employees; 2) Ethical workplace and ethical workforce. Companies should support an ethical business outlook. The company's management must be able to maintain the morality of coworkers, the morality of unit/department managers, and identify units/departments to take business ethics seriously; 3) Strong moral leadership. Companies must be able to maintain high-level morality to the Chief Executive so that it gives legitimacy and a strong moral mandate to lead as well as influential in corporate ethics. Also, overall coworkers and managers must have good ethical performance; 5) The positive influence of corporate culture and ethics. The relationship between corporate culture and business ethics undoubtedly has a positive and important impact on company assets. The Chief Executive has a role in connecting many of the company's successes such as establishing or increasing trust, motivation, harmony, loyalty, job satisfaction, pleasure and productivity with its corporate culture and business ethics.

\section{PRINCIPLES OF BUSINESS ETHICS}

In general, the principles implemented in good business activities are closely related to the norms and values system that are recognized and adopted by every social community (Silanont, 2012). Keraf (1998) explains the five essential principles in implementing business ethics as follows: 1) Autonomy. This principle implies the attitude and ability to make appropriate decisions and actions based on good ethics and norms; 2) Honesty. The principle of honesty should include in carrying out the terms of every agreement and contract, the supply of goods and services of comparable quality and price, and in internal work relationships in a company; 3) Fairness. This principle requires that any interested party should be treated equally in accordance with the rules and laws that are fair and based on the objective rational criteria, as well as accountable; 4) Mutual benefit. This principle requires that every business activity must be carried out by considering the benefit of all interested parties; 5) Moral integrity. This principle is mainly internalized as an internal demand in the business person or company so that it is necessary to perform business activities while maintaining a good image of the company.

Indeed, many large companies have to take appropriate steps towards the implementation of the principles of business ethics, despite the principle adopted may vary (Sabirin, 2016). First, establish what is known as corporate culture (corporate 
culture). This corporate culture was first built on the basis of a company's founder's vision or business philosophy as a person's appreciation of good business (Sabirin, 2016). This vision is then applied to the company, which means that this vision then becomes the attitude and behavior of the organization of the company both outward and inward (Ernawan, 2016). Then, a business ethos is to develop, a habit that was instilled in all employees since they were recruited in the company or continuously evaluated in the context of refreshment in the company (Ariesti, Yolanda \& Hia, 2014; Ernawan, 2016; Sabirin, 2016).

This ethos is the soul that unites and at the same time encourages all employees to behave and pattern the same behavior based on the principles adopted by the company (Ariesti, Yolanda \& Hia, 2014; Sabirin, 2016). Whether or not a business ethos develops is determined by the leadership style within the company

\section{PROBLEMS IN BUSINESS ETHICS}

Business ethics is a guide to distinguish between right and wrong, especially provide knowledge to every leader in the company to consider in taking strategic decisions related to the complex moral issues. However, in reality, not every company has implemented business ethics properly, most business people ignore and often violate the ethics and regulations.

Various problems in the company functions often lead to problems of business ethics, such as the functions of: 1) Accounting. The function of accounting is one of the essential components of the company. Honesty, integrity, and accuracy are conditions that must be fulfilled by this function. The problems that commonly arise in ethics in the accounting function include provides different reports for the interests of different parties, to gain benefit from the financial statements (Sukrisno, 2012). The company's internal financial statements are made differently from the financial statements for banks and tax reports. The company's accounting department intentionally changed the financial data to obtain personal profit from the preparation of these fictitious reports; 2) Finance. Misappropriation of business ethics in the financial function will cause significant losses for the investor (Sukrisno, 2012). For example, when applying for a loan from a bank, the company provides a financial statement that has been 'modified' so that it looks like the company has a good financial environment and eligible for credit. The company's financial condition is not as good as reported; 3) Production and Marketing. The relationship between companies and consumers tends to be vulnerable to ethical issues, both in production and marketing functions (Sukrisno, 2012). Problems often arise where consumers are disadvantaged by companies related to bad products. For example, problems associated with a net weight of a product, composition, or the different benefits that are informed by the manufacturer. To address these issues, the Indonesian government enacted Law No. 8 of 1999 concerning consumer protection that protects consumers from unethical practices carried out by companies; 4) Information Technology. Sophisticated technology, social media presence, and ease of transactions in cyberspace also trigger problems in the function of information technology. For instance, when a consumer submits their complaint about a product in cyberspace, then this information will quickly spread widely. If the company is not aware and pay attention to the problem wisely, it will harm the company's image (Yosephus, 2010). Other violations such as online transactions, which are often found fraudulent sites, when the buyer has made a transaction however, the goods are not sent.

Companies that uphold business ethics and moral values will prevent any actions that will harm consumers. For instance, the company immediately pull their products that are defective or do not meet the standards and can even harm consumers. 


\section{BUSINESS ETHICS AND ITS RELATION TO GOOD CORPORATE GOVERNANCE}

Each company applies different business ethics, this is because the company's operations are very diverse and specific in various units of work or function (Preble \& Reichel, 1998; Risanty \& Kesuma, 2019). In general, there are several benefits to implementing business ethics in a company (Keraf, 1998; Petersen, 2013), including: 1) Creating consumer trust. Companies that maintain business ethics and moral values will be able to increase customer loyalty. Loyalty arises because consumers believe that companies will avoid fraud and other negative actions that will detrimental to consumers; 2) Good corporate image. A better corporate image capable to give a positive response from its consumers. With this response, companies will become famous and improve their products/services; 3 ) As a motivation for employees. Employees who uphold high ethics and moral values in the work environment will have high motivation. By considering their company, gaining trust and positive responses from consumers, this will certainly make employees proud as part of the company. This also will increase morale and motivate employees to work better; 4) Generate profits for the company. With high trust, a company will enhance its image and employee motivation, so the company is able to generate an optimal profit.

Petersen (2013) postulates that trust should be built on a corporate foundation of ethical principles that consisting of transparency, competence, and integrity. Moreover, ethics plays an essential role in fraud prevention and it is a shared responsibility among members of the organization (Petersen, 2013).

The importance of business ethics in good corporate governance practices (Petersen, 2013) is as follows: ethics is the foundation of corporate governance, ethics is able to ensure the sustainability of business activities and maintain a good corporate reputation that is built on the foundation of a strong ethical culture. The application of ethical behaviors in companies will ultimately create good corporate governance (Petersen, 2013). The company management will ensure and protect the interests of the stakeholders so that the company has high responsibilities. Thus, the company will get the trust of various parties, such as creditors, shareholders, employees, and other stakeholders. And finally, the adoption of the ethical code will improve company integrity and good corporate governance.

Corporate governance will be implemented effectively if each company is committed to maintaining high integrity in implementing its activities (Risanty \& Kesuma, 2019; Sutojo \& John, 2005). With a commitment to integrity, the company will achieve high confidence of the stakeholders so that it can maintain its business for the long term (Sabirin, 2016). Moreover, the management of the company should provide accurate and relevant information for their stakeholder. In other words, a company is also required to have high accountability as well as transparency.

In order to enhance high integrity, every company must adopt ethical principles (Kurniawan, 2013). The management of a company should implement ethical behaviors in every decision to achieve high integrity. The utilitarianism and deontology can be used to deliver ethical behavior in decision-making in a company (Kurniawan, 2013; Sabirin, 2016). Decision-making does not only focus on personal or group interest, but the interest of society as a whole includes the interests of the company and its stakeholders (Oluwafisoye, \& Akande, 2013).

Moreover, solid corporate governance can be achieved by implementing a principle, best practices, fairness, honesty, integrity, and the way the company carries out all its activities (Arjoon, 2005). Although the company must be profitable to survive and grow, the achievement must remain based on ethics. Companies are also required to use a set of policies that can cover the environmental protection, whistleblowing, ethical programs 
and compliance mechanisms that can support companies to establish an image and reputation, loyalty and trust from consumers as well as enhance employees commitment and loyalty (Arjoon, 2005; El-Kassar, Messarra \& Elgammal, 2015). Moreover, ethical compliance contributes to the stability of companies because it inspires trust, leadership, management, and administration (Arjoon, 2005).

Rossouw (2005) states that corporate governance practices have different ethical properties and entire aspects become a means of ensuring that the company will act fairly, accountable, responsible and transparent. El-Kassar, Messarra \& Elgammal (2015) suggest that in order to improve corporate governance and ethical compliance, companies must: 1) Establish an ethical code, disseminated to all employees and ensure they implement the code of conduct; 2) Establish a system of reward and punishment for employees who adhere to good ethical code and those who do not, as well as protect whistleblowers; 3) Use moral strategies when providing strategic planning and making decisions; 4) Establish a program to improve and help the implementation of the corporate culture; 5) Prioritizing the interests of the organization and stakeholders above personal advantages.

Empirical evidence from previous studies has emphasized the important relationship of ethics in corporate governance. Othman \& Rahman (2011) prove that ethics plays an important and significant role in corporate governance. They point out that ethical positions (independent bodies and whistleblowers), ethical principles (corporate philosophy) and ethical structure (ethical reporting and code of ethics) are important requirements for governance practices.

Meanwhile, findings from the study of Othman \& Rahman (2012) shows that the role of ethics in corporate governance consists of three perspectives, (1) corporate governance as a code of ethics, (2) ethical inclusiveness in governance (3) ethics as an affiliate of corporate governance. In Egypt and Lebanon provide empirical evidence that ethics has a positive and significant impact on all major corporate governance categories (El-Kassar, Messarra \& Elgammal, 2015). The study provides evidence that a higher level of ethical behavior and practices will lead to better levels of corporate governance practices. In addition, the category of corporate social responsibility is predominantly influenced by the ethical category, as well as the principle of transparency, the role of the audit committee and board of directors.

In the context of companies in Indonesia, based on the Indonesian good corporate governance code, the company's basic values must include reliability, fairness and honesty and show that company values should consider the key features of the company, such as its character, sector business and geographical location (Kamal, 2010). This code of ethics also suggests that companies should implement business ethics as a guide in conducting business and interacting with stakeholders (Kamal, 2010). Moreover, this code considers that the implementation of corporate values and business ethics will sustainably support the realization of the corporate culture. And also, the code requires companies to establish business ethics and describe it in a code of ethics (Kamal, 2010).

\section{CONCLUSIONS AND RECOMMENDATIONS}

\section{Conclusions}

The weak application of corporate governance is often referred to as one of the reasons for the weak implementation of ethical behavior in business. This will cause investor mistrust so that it can have a negative impact on the business itself. Ethics plays an important role in a business, both as business conducted in the scope of private and the public sector (a government institution). The existence of ethics is expected to be a benchmark for measuring moral values, especially policies that resulted in business. 
Generally, business is only generated as a tool to achieve maximum profit. There are more important things that need to be a concern by the company and the public sector in addition to profit, namely the need for ethical business.

In principle, business activities are carried out and directed by and for humans. So, indeed it takes a set of rules that regulate so that people do not become victims of these business activities. Ethical standards established in business ethics must be a general awareness of business activities. Principles in the application of business ethics can not only be applied within the scope of private companies but can also be the scope of the public (government).

As explained earlier, business ethics has a very important relationship with the achievement of good corporate governance. Business ethics form the basis of corporate governance, resolves business competition, and the company's reputation is built on the principles of a strong ethical culture.

\section{Recommendations}

It is expected that the application of proper business ethics will provide an important role in establishing good corporate governance. Thus, the overall principles of good corporate governance will realize. The establishment of supervisory institutions is also expected to be the best way for eradicating corruption, collusion, and nepotism. Therefore, healthy business practices and the environment in Indonesia can be achieved.

\section{REFERENCES}

Akman, V. (2011). Empirical look at the factors affecting perception of business ethics in Turkey. Emerging Markets Journal, 1(1), 1-11. DOI 10.5195/emaj.2011.5

Ariesti, S., Yolanda, H., \& Hia, Y. D. (2014). Pengaruh etika bisnis dan budaya perusahaan terhadap pelaksanaan prinsip good corporate governance pada kantor pusat Bank Nagari. Jurnal Pendidikan Ekonomi, 4 (2), 1-6.

Arjoon, S. (2005). Corporate governance: An ethical perspective. Journal of Business Ethics, 61(1), 343-352

Bertens, K. (2000). Etika. Jakarta: Gramedia Pustaka Utama

Brooks, L. J., \& Dunn, P. (2012). Business \& Professional Ethics for Directors, Executives and Accountants (6th edition). Ohio: South-Western College Publishing.

Doidge, C. A. Karolyi, A. \& R. Stulz (2007). Why do countries matter so much for corporate governance? Journal of Financial Economics, 86 (1), 1-39

Effendi, M. A. (2005). Peranan etika bisnis dan moralitas agama dalam implementasi GCG. Jurnal Keuangan dan Perbankan (JKP), 2(1), 1, 49-58.

El-Kassar, A. N., Messarra, L. C., \& Elgammal, W. (2015). Effects of ethical practices on corporate governance in developing countries: Evidence from Lebanon and Egypt. Journal of Corporate Ownership \& Control, 12 (3), 494-504

Ernawan, E. R. (2016). Etika Bisnis. Bandung: Penerbit Alfabeta

Gamal, E. D.A. (2009). A Pause for Self-Assessment. The Executive Quarterly, 1, 2-3.

Ip, P. K. (2003). Business ethics and a state-owned enterprise in China. Business Ethics: A European Review, 12(1), 64-77. https://doi.org/10.1111/1467-8608.00306

Johnson, G., \& Scholes, K. (1998). Evaluation in Strategic Management. New Jersey: Prentice Hall

Kamal, M. (2010). Corporate governance and state-owned enterprises: A study of Indonesia's code of corporate governance. Journal of International Commercial Law and Technology, 5(4), 206-224.

Keraf, S. (1998). Etika Bisnis: Tuntutan dan Relevansinya. Yogyakarta: Penerbit Kanisius.

Kurniawan, A. (2013). Etika bisnis di Indonesia. Jurnal Akuntansi, 15(01), 1-30. 
Magdalena, L. (1992). Ensiklopedia Ekonomi, Bisnis, dan Manajemen. Jakarta: Cipta Adi Pustaka

Oluwafisoye, O. \& Akande, O. (2013). Business Ethics and Corporate Social Responsibility: The perception of employees on business ethics in an organization. (Master's thesis). School of Management, Blekinge Tekniska Högskola. Available at: https://www.diva-portal.org/smash/get/diva2\%3A831055/FULLTEXT01.pdf

Othman, Z. \& Rahman, R. A. (2011). Exploration of ethics as moral substance in the context of corporate governance. Asian Social Sciences, 7(8), 173-182.

Othman, Z., Rahman, R. A., \& Shamsudin, F. M. (2012). The role of ethics in corporate governance. Jurnal Pengurusan. 35, 13 - 20.

Petersen, A. (2013). The Importance of Governance and Business Ethics. Chartered Institute of Purchasing and Supply of Africa.

Post, J.E., L. Preston, \& S. Sachs (2002). Managing the extended enterprise: The new takeholder view. California Management Review, 45 (1), 6-28

Preble, J. F., \& Reichel, A. (1998). Attitude toward business ethics of future managers in the USA and Isreal . Journal of Business Ethics, 7(12), 941 - 949

Ramakrishnan, R. (2007). Inter-relationship between business ethics and corporate governance among Indian Companies. International Seminar At The Institute of Management, NIRMA University, Ahmadabad. https://ssrn.com/abstract $=1751657$

Risanty, R., \& Kesuma, S. A. (2019). Good university governance: experience from Indonesian university. Jurnal Perspektif Pembiayaan Dan Pembangunan Daerah, 6(4), 515-524. https://doi.org/10.22437/ppd.v6i4.6195

Rossouw, G. J. (2005). Business ethics and corporate governance in Africa. Business \& Society, 44(1), 94-106.

Sabirin, S. (2016). Etik dan Good Corporate Governance (GGC) Sebuah Cara Mewujudkan Entitas Bisnis yang Sehat. Kompasiana Ekonomi. Available at: https://www.kompasiana.com/sabirinsaiga/57df999e7593733941aef017/etik-dangood-corporate-governance-ggc-sebuah-cara-mewujudkan-entitas-bisnis-yangsehat?page $=$ all.

Sari, K. (2011). Pengaruh etika bisnis, pedoman perilaku, pemegang saham dan kebijakan dividen terhadap implementasi GCG pada Bank Sumut. (Master's thesis). Universitas Sumatera Utara.

Silanont, S. P. (2012). Business ethics perception of thai workforce: a study of age, gender, education, management experience and ethics training. School of Business and Technology of Webster University

Sukrisno, A. (2012). Etika Bisnis dan Profesi. Jakarta: Penerbit Salemba Empat

Sutojo, S., \& John, A. E. (2005). Good Corporate Governance: Tata Kelola Perusahaan Yang Sehat. Jakarta: PT.Damar Mulia Rahayu

Yosephus, S. (2010). Etika Bisnis: Pendekatan Filsafat Moral Terhadap Perilaku Pembisnis Kontemporer. Jakarta: Yayasan Pustaka Obor

Zabihollah, R. (2009). Corporate Governance and Ethics. USA: John Wiley and Sons.

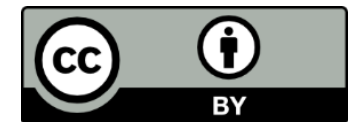

(C) 2020 by the authors. Licensee JPPD, Indonesia. This article is an open access article distributed under the terms and conditions of the Creative Commons Attribution (CC BY) license (http://creativecommons.org/licenses/by/4.0/). 